\title{
Review of the Causes of Students' Lack of Reception of Vocational Schools of Arts
}

\section{Seyed Reza Balaghat}

University of Sistan and Baluchestan; balaghat@edpsy.usb.ac.ir

\author{
Abedeh Nazari \\ University of Sistan and Baluchestan; Nazari@ped.usb.ac.ir
}

Farahnaz Badini

MA of Educational Administration form University of Sistan and Baluchestan

Doi:10.5901/mjss.2016.v7n2s2p176

\begin{abstract}
The purpose of the present research is to review the causes of lack of reception of students of vocational schools of arts. The statistical population has been composed of 16 counselors, 588 students and 588 parents and in proportion with the Delphi method, 16 consultants, 58 students and 58 parents were selected in which the consultants were selected through census and students and their parents were selected randomly. By using the researcher-made questionnaire, data was gathered and the obtained data was analyzed by using the indexes of descriptive and inferential statistics. The results obtained from the research are: in total, 30 causes of lack of reception of vocational institutes have been recognized; in which field, in terms of consultants, based on their opinions, the first priorities are in the field educational factors, lack of success of vocational course in creating and presenting educations in proportion with the need of working market, cultural and social factors: priority of employment, economic factors: duration of the time of unemployment of graduates, individual factors: lack of curiosity associated with the way technical tools work are among them. Also in terms of students, based on students' opinions, the first priorities are in the field of educational factors of making undesirable connections between the system of education and occupation, cultural and social factors: social value and status of technical vocational education, economical factors: rate of income and individual factors: unawareness of vocational majors.
\end{abstract}

Keywords: Causes of Lack of Reception, Educational, Cultural and Social, Economical, Individual Factors

\section{Introduction}

Vocational educations are activities prepared by a person to obtain profession, employment and work or increase his or her efficiency and ability in doing them (Sarizadi and Sarizadi, 2012, p 15). Vocational educations are efficient tools for realizations of the purposes written in upstream documents such as vision document; because among purposes of vision document are the realization of a population with improved knowledge and supreme share of human capital in national production and existence of a proper system of vocational education which are among the necessary requirements of achieving such purposes. Thus, as the fourth program continues, the fifth program of development has also emphasized this by using these tools for realizing the purposes of the program which itself is a part of the programs of vision realization (Hossein Zadeh Yoosefi, 2012, p 12). One of the important issues faced by the vocational system is how talented students are encouraged, conducted and attracted to be interested in and join these educations. It is inferred from the results of researches and reviews in this regard that unfortunately, most of the students don't welcome vocational and technical and these educations have had negative growth in terms of the number of students in comparison with theoretical educations and students are mostly attracted to theoretical majors (Jamal Zadeh and Yar Mohammadian, 1998, p 139).

\section{Expression of the Issue}

Today, in many countries, vocational education is officially and unofficially effective in the enhancement of the productions of the society and among the members of a society, it is responsible for transmission of skills and it leads to 
the facilitation and acceleration in the process of the economical growth of society by developing the available skills and introducing new individuals to the working market (Carnoy, 1995, p 32). Also, vocational education is a way for creating effective and efficient workforce and an index for country's national success, because the quality of the programs of vocational education independently depends on the enhancement of production, quality and efficiency of society's workforce (Cornford, 1999, p 64).

Also in a research, Lankarani (2001) reviewed the executive problems of vocational and technical educations in the educational units in the opinion of art students, teachers and managers of the city Isfahan. His research showed that problems are: disproportion of facilities and equipments of schools of art, disproportion of academic majors with the interest art students, disproportion of curriculum, teaching methods and theoretical and operational testing method with the learners' needs were confirmed; also issues such as graduates' unemployment, incompliance of job with profession, lack of proper transmission of graduates from school to work, inefficient graduates, incompliance between the skills of graduate with the needs of the working market, injecting inefficient students to schools of art, improper academic improvement, lack of participation or low participation of industry, establishment of these schools without considering regional needs and low rate of interest in registering in them and also concentrated curriculum have been mentioned as limitations an challenges of this system in many countries (Ghost, 2002, p 62; Billett, 2004, p 20; and Schaapa, et al. 2009, p 490). Balanced development of academic majors with the view of combined courses (qualitative and quantitative) is among those items which always occur as a serious challenge especially in the domain of vocational education.

Halasz (1989), in a general classification, has divided the consequences of vocational schools into two groups: "economic consequences" and "noneconomic consequences". And he believes that economic consequences directly influence the working market; whereas noneconomic consequences have an indirect, intangible and supporting impact on the working market. The factor of "consequences of the working market" is considered as one of the most common vocational economic factors which is composed of indications such as "proportion of job with the academic major", "time period of unemployment", "satisfaction of employers", "rate of income" and employment per capita (Dronkers, 1993, p 200; Ainsworth and Roscing, 2005, p 274). Also the "rate of admission to higher education", "qualification of the learners" and "realization of social and educational purposes" and "cultural factors" are also considered as noneconomic factors (USA's education sector, 2001; Ainsworth and Roscing, 2005). Given what the vocational group of Qazvin province (2009), Halaz (1989, p 111), USA's education sector (2001), (Ainsworth and Roscing, 2005, p 274), Ghost (2002, p 62), Billett (2004, p 17) and Schaap, et al. (2009, p 487) have said about the main vocational problems and challenges in Iran and throughout the world; these problems and challenges can be considered as effective factors on the tendency and lack of tendency of students for studying in the branch of work and vocational education; and given the researches of Sharifi and Islamieh (2012), these can be categorized in four educational, cultural and social, economic and individual classes. Since the mentioned factors can be effective on the students' approach to vocational education; thus in this research, by using the Delphi technique, which is used for public agreement and consensus among members about a special issue (Saunders and Lewis, 2003, p 145), in the present research we are seeking to specify this: which are the educational, cultural and social, economic and individual factors that affect lack of reception of students of vocational schools of art?

\section{General Question}

Which are the effective causes of the reception of high school girl students of the theoretical branch of the city Zahedan of the vocational schools of art in order of preference?

Special questions:

1. In consultants' opinion, which are the effective educational, cultural and social, economic and individual factors on the lack of reception of high school girl students of the theoretical branch of the city Zahedan of the vocational schools of art in order of preference?

2. In parents' opinion, which are the effective educational, cultural and social, economic and individual factors on the lack of reception of high school girl students of the theoretical branch of the city Zahedan of the vocational schools of art in order of preference?

3. In students' opinion, which are the effective educational, cultural and social, economic and individual factors on the lack of reception of high school girl students of the theoretical branch of the city Zahedan of the vocational schools of art in order of preference? 


\section{Importance and Necessity of the Research}

Undoubtedly, the education system is considered as the infrastructure of the growth and development of countries and it is mentioned as the "industry of growth" (Adnan and Smith, 2002, p 241). Vocational education system as one of the important components of countries' education system is the main attendant of the education of the skilled and semiskilled human force at the level of university (Tilak, 2002, p 240). Educating human force with the intention of development of efficient and effective human capital on development is considered to be one of the important tasks of this system. The role of this system is very crucial from the perspective of the human force required by the countries in comparison with theoretical education (Winch, 2002, p 101); therefore, investing in it has turned into one of the basic policies of the countries (Kazamias and Roussakis, 2003, p 22).

These educations, by combining the theoretical and operational educations, has provided this possibility for the graduates so that they would have more alignment with the needs of the working market and through this, it provides a better condition for their interest in economic and social activities (Salimi Fard and Mortazavi, 2005, p 65). More than three decades have passed since the development of human capital theory. In this period, the role and importance of vocational education in the economic development has been recognized for the developed countries and many of the developing countries; in a way that many countries have attempted to reform their vocational education system and to invest in it for creating evolution in economic development as the background and the first step (Akhlaghi, 2006, p 67).

Azad (2006), in the discussion of pathology of vocational system, has reviewed the rate of effectiveness of vocational education and the rate of efficiency of the elements of vocational education system and has considered the curricula to be inefficient and ineffective due to the lack or shortage of human force with qualification, improper equipments, management without insufficient professional qualification and insufficient space. And he also believed that attempting for reformation and revision in the domain of methods and purposes in proportion with the economic, social, cultural and value conditions of each country are required and necessary (Azad, 2006, p 24). Therefore, the importance and necessity of the present research is that in today's skillful world, vocational education can play a very important role in a person's achieving success and improvement in his or her professional and social life and that is the cause why parents who aren't aware of the basic functions of vocational education and don't consider this type of education as entertainment and fun and families don't force their children to get official and governmental jobs and force them to study majors with physical and handy works as a result.

\subsection{Research background}

- Riahi (2005), by reviewing the social and family factors associated with selecting training fields in the centers of vocational education of Mazandaran province showed that the family, social and individual factors of the person are effective in his tendency or lack of tendency.

- Saharkhiz (2011) stated that the major causes of lack of students' reception of education in vocational and technical fields are the lack of information of the students of the possibility of studying these fields to the PhD level, improper usage of financial sources and demonstrating the vocational education to be inefficient in the country.

- Azad (2006), in a research, states that the causes of lack of tendency of talented students towards the vocational branch as follows: talented students don't have so much information about the vocational field and in their opinions; those who are interested in technical fields can achieve their goals by admitting in schools of arts as well.

- Sharifi and Islamieh (2012), in a research entitled as causes of tendency and lack of tendency towards vocational educations, showed that five cultural and social, economic, individual, technical and infrastructural factors and the factor of working market play a role as effective factors on lack of tendency of students' towards vocational educations. It shall be noted that the shares of cultural, social and individual factors have been more than others in the field above.

\subsection{Research's theoretical framework}

Studies show that educational, economic, social, individual and family factors are effective on the students' tendency and lack of tendency towards vocational educations. According to this, given the theoretical and experimental studies, the conceptual model of the research was designed (figure, 2-1). 


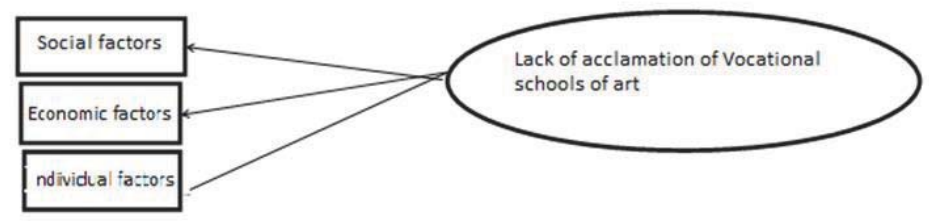

Figure 2 - 1: research's conceptual model

\subsection{Research method}

The present study is of the quantitative type in terms of nature and of the applicable type in terms of application and descriptive - survey type in terms of the method of data gathering. In this research, in order to recognize the causes of lack of reception of high school girl students of the theoretical branch of the city Zahedan of the vocational schools of art, the Delphi method has been used. This method has been innovated with this purpose that the group opinions are used to the maximum extent and to minimize the incompliance and disagreement (Lo0, 2002). This method is done in several courses and with the participation of individuals who are involved in the subject of the research. The number of periods is averagely and usually three periods in each of which the questions associated with the required subject have been codified in the form of open-response and closed-response questionnaires and it is sent to those individuals. The obtained results in each period are used as the basis of the next periods; in such way that after gathering and analyzing the responses of the first period, the second period is codified based on them and they are once again returned in order to gather the individuals' opinions. The third period also continues with the same method. In stages of this method, scales such as Likert spectrum can be used for classification (Sarmad, et al. 2008, p 117).

\section{Statistical Population, Statistical Sample and Sampling Method}

The volume of the studied population is composed of school consultants and junior high school students of the theoretical branch of the city Zahedan in the academic year of $2012-2013$. The statistical population has been composed of 16 consultants and 588 students and in proportion with the Delphi method, 16 consultants, 58 students and 58 parents were selected in which the consultants were selected through census and students and their parents were selected randomly.

\subsection{Measurement tools and its implementation method}

The main tools of the study are the researcher-made open-response and closed-response questionnaires which were designed by using the Delphi technique in three periods.

\subsection{Validity and reliability of the data gathering tools}

The student questionnaire has 28 questions and the consultant questionnaire has 20 questions and 4 components and a number of 5 questionnaires were distributed among professors and reporters of the field of management, educational management and psychology and the formal validity of the questionnaire was confirmed by applying their opinions. In order to determine the reliability of the questionnaires, the Cronbach alpha coefficient was used.

\section{Analysis of the Research Findings}

First question of the research: In students' opinion, which are the effective educational, cultural and social, economic and individual factors on the lack of reception of high school girl students of the theoretical branch of the city Zahedan of the vocational schools of art in order of preference?

In order to review this question, the single-variable t-test was used and its results were presented in table (4-1). 
Table 4-1: recognition of effective factors on lack of reception of vocational schools of art in students' opinion

\begin{tabular}{|c|c|c|c|c|c|c|}
\hline \multicolumn{2}{|c|}{ Index } & \multirow{2}{*}{\begin{tabular}{c|} 
Mean \\
2.76 \\
\end{tabular}} & \multirow{2}{*}{$\begin{array}{c}\begin{array}{c}\text { Standard } \\
\text { deviation }\end{array} \\
1.08 \\
\end{array}$} & \multirow{2}{*}{\begin{tabular}{|c|}
$\begin{array}{c}\text { t- } \\
\text { value }\end{array}$ \\
3 \\
\end{tabular}} & \multirow{2}{*}{\begin{tabular}{|c|}
$\mathbf{t}$ \\
8.44 \\
\end{tabular}} & \multirow{2}{*}{\begin{tabular}{|c|} 
Sig \\
0.00
\end{tabular}} \\
\hline $1-$ & Lack of satisfaction of the graduates of their skill and performance in doing job tasks & & & & & \\
\hline $2-$ & $\begin{array}{l}\text { Lack of success of vocational courses in creating and presenting educations in proportion } \\
\text { with the need of working market }\end{array}$ & 3.38 & 0.96 & 3 & 7.22 & 0.00 \\
\hline 3- & $\begin{array}{l}\text { Lack of success of vocational courses in presenting sufficient education to graduates in } \\
\text { order to successful absorption in the working market }\end{array}$ & 3.89 & 1.13 & 3 & 7.25 & 0.00 \\
\hline 4- & Establishment of undesirable relationship between education system and occupation & 4.85 & 1.56 & 3 & 8.53 & 0.00 \\
\hline 5- & $\begin{array}{l}\text { Lack of success of the vocational periods in learning the techniques and skills needed by } \\
\text { the society }\end{array}$ & 3.80 & 1.24 & 3 & 8.08 & 0.00 \\
\hline 6- & Reduction of the feeling of curiosity and creativity in students & 3.63 & 1.15 & 3 & 8.86 & 0.00 \\
\hline 7- & $\begin{array}{l}\text { Not bringing up the ability of making decisions in solving issues and stability against } \\
\text { problems }\end{array}$ & 3.65 & 0.94 & 3 & 8.08 & 0.00 \\
\hline $8-$ & Lack of reinforcement of the spirit of being hardworking in the graduates & 2.87 & 1.01 & 3 & 7.22 & 0.00 \\
\hline 9- & Close or far distance of the location of the vocational educational centers & 3.94 & 1.28 & 3 & 7.22 & 0.00 \\
\hline $10-$ & Improperness of workshop equipments and facilities & 3.94 & 1.28 & 3 & 8.53 & 0.00 \\
\hline 11- & Inability to recognize the laws of work and job relations in graduates & 2.25 & 1.28 & 3 & 4.37 & 0.00 \\
\hline $12-$ & The impact of social media such as television & 3.28 & 1.30 & 3 & 2.90 & 0.02 \\
\hline $13-$ & Giving entitlements & 2.92 & 1.21 & 3 & 1.29 & 0.14 \\
\hline $14-$ & Social value and status of vocational education & 3.90 & 1.34 & 3 & 14.36 & 0.00 \\
\hline $15-$ & The rate of specialization of the job & 3.16 & 1.32 & 3 & 3.97 & 0.00 \\
\hline $16-$ & Priority of employment & 3.18 & 1.27 & 3 & 2.56 & 0.02 \\
\hline $17-$ & Self-employment loan & 3.76 & 1.27 & 3 & 10.96 & 0.00 \\
\hline $18-$ & Society's need for a special field & 3.45 & 1.20 & 3 & 2.60 & 0.02 \\
\hline $19-$ & Rate of income & 3.98 & 1.25 & 3 & 14.36 & 0.00 \\
\hline $20-$ & Continuity of education at higher levels & 2.90 & 1.01 & 3 & 9.59 & 0.00 \\
\hline $21-$ & Occupation status of the graduates & 3.95 & 0.95 & 3 & 3.97 & 0.00 \\
\hline $22-$ & Proportion of graduates' job or the academic field & 2.85 & 1.10 & 3 & 10.96 & 0.00 \\
\hline $23-$ & Lack of satisfaction of employers of graduates' scientific knowledge & 2.40 & 1.22 & 3 & 4.37 & 0.00 \\
\hline $24-$ & Lack of satisfaction of employers of graduates' operational knowledge & 3.54 & 1.01 & 3 & 14.36 & 0.00 \\
\hline $25-$ & Lack of satisfaction of employers of graduates' professional performance & 3.85 & 1.18 & 3 & 3.37 & 0.00 \\
\hline $26-$ & Unawareness of vocational fields & 3.70 & 1.09 & 3 & 8.86 & 0.00 \\
\hline & Lack of interest in operational, workshop and vocational courses & 2.69 & 1.44 & 3 & 7.22 & 0.00 \\
\hline $28-$ & Curiosity about how technical tools work & 3.18 & 1.40 & 3 & 2.48 & 0.00 \\
\hline
\end{tabular}

Given the results of the table (4-1), in order to prioritize the recognized factors of the lack of reception of vocational schools of arts in students' opinion, the Friedman test was used. Priorities of lack of reception of students of vocational schools of arts in four categories - educational, cultural and social, economic and individual factors have been provided in table (4-2).

Table 4-2: Prioritization of the recognized educational factors of the lack of reception of vocational schools of arts in students' opinion

\begin{tabular}{|c|c|c|c|c|}
\hline & Inde & & Mean of ranks & Priority \\
\hline & 1. & Lack of satisfaction of the graduates of their skill and performance in doing job tasks & 1.98 & 10 \\
\hline & & $\begin{array}{l}\text { Lack of success of vocational courses in creating and presenting educations in proportion with the need } \\
\text { of working market }\end{array}$ & 4.24 & 5 \\
\hline m & & $\begin{array}{l}\text { Lack of success of vocational courses in presenting sufficient education to graduates in order to } \\
\text { successful absorption in the working market }\end{array}$ & 5.87 & 3 \\
\hline & 4. & Establishment of undesirable relationship between education system and occupation & 6.69 & 1 \\
\hline 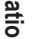 & 5. & Lack of success of the vocational periods in learning the techniques and skills needed by the society & 3.76 & 6 \\
\hline 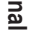 & 6. & Reduction of the feeling of curiosity and creativity in students & 2.99 & 8 \\
\hline & & Not bringing up the ability of making decisions in solving issues and stability against problems & 3.70 & 7 \\
\hline & 8. & Lack of reinforcement of the spirit of being hardworking in the graduates & 2.30 & 9 \\
\hline & & Close or far distance of the location of the vocational educational centers & 5.18 & 4 \\
\hline & & Improperness of workshop equipments and facilities & 6.34 & 2 \\
\hline
\end{tabular}


As we see in the table 4-2, in students' opinion, in the field of educational factors, the index of establishment of undesirable relationship between occupation and education system has the highest score and lack of satisfaction of the graduates of their skills and performance in doing their job tasks has the lowest score in lack of reception of students of vocational schools of arts. Also, given the results of table (4-3), this difference is significant at the level of $99 \%$.

Table 4-3: Significance of Friedman test for factors associated with educational factors

\begin{tabular}{|l|c|}
\hline Statistical indexes & Calculated rates \\
\hline Sample & 58 \\
\hline Chi-square & 475.45 \\
\hline Degree of freedom & 9 \\
\hline Significance level & 0.00 \\
\hline
\end{tabular}

Priorities of cultural and social factors of students' lack of reception of vocational schools of arts have been provided in table (4-4).

Table 4-4: Prioritization of the recognized factors of the lack of reception of vocational schools of arts in students' opinion

\begin{tabular}{|c|c|c|c|c|}
\hline 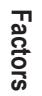 & \multicolumn{2}{|c|}{ Index } & \multirow{2}{*}{\begin{tabular}{|c|} 
Mean of ranks \\
2.33 \\
\end{tabular}} & \multirow{2}{*}{\begin{tabular}{|c|} 
Priority \\
8
\end{tabular}} \\
\hline \multirow{8}{*}{ 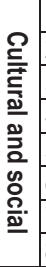 } & 1- & Inability to recognize the laws of work and job relations in graduates & & \\
\hline & & The impact of social media such as television & 3.90 & 4 \\
\hline & $3-$ & Giving entitlements & 2.99 & 7 \\
\hline & $4-$ & Social value and status of vocational education & 5.57 & 1 \\
\hline & & The rate of specialization of the job & 3.14 & 6 \\
\hline & $6-$ & Priority of employment & 3.79 & 5 \\
\hline & $7-$ & Self-employment loan & 5.12 & 2 \\
\hline & & Society's need for a special field & 4.68 & 3 \\
\hline
\end{tabular}

As we see in the table 4-2, in students' opinion, in the field of educational factors, the index of the impact of social media such as television has the highest score and Inability to recognize the laws of work and job relations in graduates has the lowest score in lack of reception of students of vocational schools of arts. Also, given the results of table (4-3), this difference is significant at the level of $99 \%$.

Table 4-5: Significance of Friedman test for factors associated with cultural and social factors

\begin{tabular}{|l|c|}
\hline Statistical indexes & Calculated rates \\
\hline Sample & 58 \\
\hline Chi-square & 179.74 \\
\hline Degree of freedom & 7 \\
\hline Significance level & 0.00 \\
\hline
\end{tabular}

Priorities of economic factors of students' lack of reception of vocational schools of arts have been provided in table (4-4).

Table 4-6: Prioritization of the recognized economic factors of the lack of reception of vocational schools of arts in students' opinion

\begin{tabular}{|c|c|c|c|}
\hline 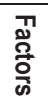 & Index & Mean of ranks & Priority \\
\hline \multirow{4}{*}{$\begin{array}{l}\text { mo } \\
\text { o } \\
\text { 을. } \\
\text { 흐. }\end{array}$} & 1- Rate of income & 5.67 & 1 \\
\hline & 2- Continuity of education at higher levels & 3.89 & 5 \\
\hline & 3- $\quad$ Occupation status of the graduates & 5.12 & 2 \\
\hline & 4- Proportion of graduates' job or the academic field & 3.50 & 6 \\
\hline
\end{tabular}




\begin{tabular}{|l|lll|l|l|}
\hline \multirow{2}{*}{$5-$} & Lack of satisfaction of employers of graduates' scientific knowledge & 3.03 & 7 \\
\cline { 2 - 5 } & $6-$ & Lack of satisfaction of employers of graduates' operational knowledge & 4.12 & 4 \\
\cline { 2 - 5 } & $7-$ & Lack of satisfaction of employers of graduates' job performance & 4.58 & 3 \\
\hline
\end{tabular}

As we see in the table 4-6, the index of rate of income has the highest score and lack of satisfaction of the employers of the scientific knowledge of graduates has the lowest score in lack of reception of students of vocational schools of arts. Also, given the results of table (4-7), this difference is significant at the level of $99 \%$.

Table 4-7: Significance of Friedman test for factors associated with economic factors

\begin{tabular}{|l|c|}
\hline Statistical indexes & Calculated rates \\
\hline Sample & 58 \\
\hline Chi-square & 139.74 \\
\hline Degree of freedom & 6 \\
\hline Significance level & 0.00 \\
\hline
\end{tabular}

Priorities of individual factors of students' lack of reception of vocational schools of arts have been provided in table (4-8).

Table 4-8: Prioritization of the recognized individual factors of the lack of reception of vocational schools of arts in students' opinion

\begin{tabular}{|c|c|c|c|}
\hline 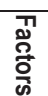 & Index & Mean of ranks & Priority \\
\hline \multirow{3}{*}{$\begin{array}{l}\overline{\bar{a}} \\
\text { 흘 } \\
\text { 흘 }\end{array}$} & 1- Unawareness of vocational fields & 4.46 & 1 \\
\hline & 2- $\quad$ Lack of interest in operational, workshop and vocational courses & 3.67 & 3 \\
\hline & 3- Curiosity about how technical tools work & 4.18 & 2 \\
\hline
\end{tabular}

As we see in the table 4-8, the index of unawareness of vocational fields has the highest score and Lack of interest in operational, workshop and vocational courses has the lowest score in lack of reception of students of vocational schools of arts. Also, given the results of table (4-9), this difference is significant at the level of $99 \%$

Table 4-7: Significance of Friedman test for factors associated with economic factors

\begin{tabular}{|l|c|}
\hline Statistical indexes & Calculated rates \\
\hline Sample & 58 \\
\hline Chi-square & 111.37 \\
\hline Degree of freedom & 2 \\
\hline Significance level & 0.00 \\
\hline
\end{tabular}

Second question of the research: In consultants' opinion, which are the effective educational, cultural and social, economic and individual factors on the lack of reception of high school girl students of the theoretical branch of the city Zahedan of the vocational schools of art in order of preference?

In order to review this question, the single-variable t-test was used and its results were presented in table (4-9).

Table 4-10: Recognition of effective factors on lack of reception of vocational schools of art in consultants' opinion

\begin{tabular}{|c|c|c|c|c|c|c|}
\hline \multicolumn{2}{|c|}{ Index } & \multirow{2}{*}{\begin{tabular}{|l} 
Mean \\
3.75
\end{tabular}} & \multirow{2}{*}{\begin{tabular}{|c|}
$\begin{array}{c}\text { Standard } \\
\text { deviation }\end{array}$ \\
0.97 \\
\end{tabular}} & \multirow{2}{*}{\begin{tabular}{|c|}
$\begin{array}{c}\mathrm{t}- \\
\text { value }\end{array}$ \\
3
\end{tabular}} & \multirow{2}{*}{\begin{tabular}{|c|}
$t$ \\
4.37
\end{tabular}} & \multirow{2}{*}{$\begin{array}{l}\text { Sig } \\
0.00\end{array}$} \\
\hline & Lack of $\mathrm{s}$ & & & & & \\
\hline & $\begin{array}{l}\text { Lack of success of vocational courses in creating and presenting educations in } \\
\text { proportion with the need of working market }\end{array}$ & 4.50 & 0.99 & 3 & 3.97 & 0.00 \\
\hline & $\begin{array}{l}\text { Lack of success of vocational courses in presenting sufficient education to graduates } \\
\text { in order to successful absorption in the working market }\end{array}$ & |3.57 & 1.18 & 3 & & 0.00 \\
\hline & Establishment of undesirable relationship between education system and occupation & 3.95 & 1.13 & 3 & 4.25 & 0.0 \\
\hline
\end{tabular}




\begin{tabular}{|c|c|c|c|c|c|}
\hline $\begin{array}{l}\text { 5- Lack of success of the vocational periods in learning the techniques and skills } \\
\text { needed by the society }\end{array}$ & 2.72 & 1.06 & 3 & 14.36 & 0.00 \\
\hline 6- Reduction of the feeling of curiosity and creativity in students & 3.67 & 1.50 & 3 & 9.25 & 0.00 \\
\hline $\begin{array}{l}\text { 7- Not bringing up the ability of making decisions in solving issues and stability against } \\
\text { problems }\end{array}$ & 2.93 & 1.09 & 3 & 7.37 & 0.00 \\
\hline 8- Lack of reinforcement of the spirit of being hardworking in the graduates & 4.13 & 1.06 & 3 & 8.15 & 0.00 \\
\hline 9- Close or far distance of the location of the vocational educational centers & 3.80 & 0.56 & 3 & 9.59 & 0.00 \\
\hline 10- Improperness of workshop equipments and facilities & 4.26 & 1.13 & 3 & 4.25 & 0.00 \\
\hline 11- Inability to recognize the laws of work and job relations in graduates & 3.33 & 1.11 & 3 & 4.25 & 0.00 \\
\hline 12- The impact of social media such as television & 3.60 & 1.12 & 3 & 8.27 & 0.02 \\
\hline 13- Giving entitlements & 4.50 & 1.09 & 3 & 13.42 & 0.14 \\
\hline 14- Social value and status of vocational education & 2.66 & 1.05 & 3 & 4.48 & 0.00 \\
\hline 15- The rate of specialization of the job & 2.47 & 1.06 & 3 & 9.25 & 0.00 \\
\hline 16- Priority of employment & 4.40 & 1.05 & 3 & 14.36 & 0.02 \\
\hline 17- Self-employment loan & 4.4 & 1.05 & 3 & 14.36 & 0.00 \\
\hline 18- Society's need for a special field & 4.13 & 0.99 & 3 & 4.37 & 0.02 \\
\hline 19- Rate of income & 4.86 & 0.35 & 3 & 10.96 & 0.00 \\
\hline 20- Continuity of education at higher levels & 5.00 & 0.00 & 3 & 9.59 & 0.00 \\
\hline
\end{tabular}

Given the results of the table (4-10), in order to prioritize the recognized factors of the lack of reception of vocational schools of arts in consultants' opinion, the Friedman test was used. Priorities of educational factors of lack of reception of students of vocational schools of arts in four categories - educational, cultural and social, economic and individual factors have been provided in table (4-11).

Table 4-11: Prioritization of the recognized educational factors of the lack of reception of vocational schools of arts in consultants' opinion

\begin{tabular}{|c|c|c|c|}
\hline 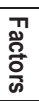 & Index & $\begin{array}{c}\text { Mean of } \\
\text { ranks }\end{array}$ & Priority \\
\hline \multirow{6}{*}{ 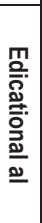 } & 1. Lack of satisfaction of the graduates of their skill and performance in doing job tasks & 5.12 & 3 \\
\hline & $\begin{array}{l}\text { 2. Lack of success of vocational courses in creating and presenting educations in proportion with the need } \\
\text { of working market }\end{array}$ & 6.95 & 1 \\
\hline & 3. Lack of success of the vocational periods in learning the techniques and skills needed by the society & 3.72 & 5 \\
\hline & 4. Reduction of the feeling of curiosity and creativity in students & 5.75 & 2 \\
\hline & 5. Lack of reinforcement of the spirit of being hardworking in the graduates & 2.50 & $\frac{5}{6}$ \\
\hline & 6. Improperness of workshop equipments and facilities & 4.24 & 4 \\
\hline
\end{tabular}

As you see in the table 4-11, the index of Lack of success of vocational courses in creating and presenting educations in proportion with the need of working market has the highest score and lack of reinforcement of the spirit of being hardworking in the graduates has the lowest score in lack of reception of students of vocational schools of arts. Also, given the results of table (4-12), this difference is significant at the level of $99 \%$.

Table 4-3: Significance of Friedman test for factors associated with educational factors

\begin{tabular}{|l|c|}
\hline Statistical indexes & Calculated rates \\
\hline Sample & 16 \\
\hline Chi-square & 67.37 \\
\hline Degree of freedom & 9 \\
\hline Significance level & 0.00 \\
\hline
\end{tabular}

Priorities of cultural and social factors of students' lack of reception of vocational schools of arts have been provided in table (4-13). 
Table 4-13: Prioritization of the recognized factors of the lack of reception of vocational schools of arts in consultants' opinion

\begin{tabular}{|c|c|c|c|}
\hline 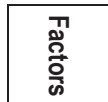 & Index & Mean of ranks & Priority \\
\hline \multirow{3}{*}{ 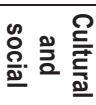 } & 1- $\quad$ Giving entitlements & 1.80 & 3 \\
\hline & 2- $\quad$ Priority of employment & 2.13 & 1 \\
\hline & 3- $\quad$ Society's need for a special field & 1.93 & 2 \\
\hline
\end{tabular}

As table 4-13 shows, the index of the priority of employment has the highest score and giving entitlements has the lowest score in lack of reception of students of vocational schools of arts. Also, given the results of table (4-14), this difference is significant at the level of $99 \%$.

Table 4-14: Significance of Friedman test for factors associated with cultural and social factors

\begin{tabular}{|l|c|}
\hline Statistical indexes & Calculated rates \\
\hline Sample & 16 \\
\hline Chi-square & 57.37 \\
\hline Degree of freedom & 2 \\
\hline Significance level & 0.00 \\
\hline
\end{tabular}

Priorities of economic factors of consultants' lack of reception of vocational schools of arts have been provided in table (415).

Table 4-15: Prioritization of the recognized economic factors of the lack of reception of vocational schools of arts in consultants' opinion

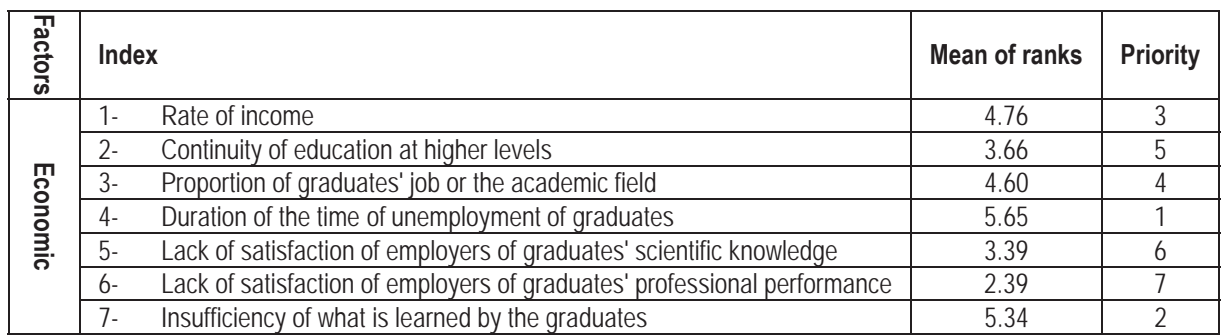

As table 4-15 shows, the index of duration of the time of unemployment of the graduates has the highest score and lack of satisfaction of the employers of the professional performance of graduates has the lowest score in lack of reception of students of vocational schools of arts. Also, given the results of table (4-16), this difference is significant at the level of $99 \%$.

Table 4-16: Significance of Friedman test for factors associated with economic factors

\begin{tabular}{|l|c|}
\hline Statistical indexes & Calculated rates \\
\hline Sample & 16 \\
\hline Chi-square & 43.37 \\
\hline Degree of freedom & 6 \\
\hline Significance level & 0.00 \\
\hline
\end{tabular}

Priorities of individual factors of consultants' lack of reception of vocational schools of arts have been provided in table (417). 
Table 4-17: Prioritization of the recognized individual factors of the lack of reception of vocational schools of arts in consultants' opinion

\begin{tabular}{|c|c|c|c|}
\hline $\begin{array}{l}\text { गे } \\
\stackrel{0}{0} \\
\text { 웅 }\end{array}$ & Index & Mean of ranks & Priority \\
\hline \multirow{4}{*}{ 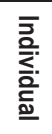 } & 1- $\quad$ Feeling you don't need to acquire skills & 2.89 & 3 \\
\hline & 2- Unawareness of vocational fields & 2.54 & 4 \\
\hline & 3- Lack of interest in operational, workshop and vocational courses & 3.16 & 2 \\
\hline & Curiosity about how technical tools work & 3.57 & 1 \\
\hline
\end{tabular}

As you see in the table 4-8, the index of Curiosity about how technical tools work has the highest score and unawareness of vocational fields has the lowest score in lack of reception of students of vocational schools of arts. Also, given the results of table (4-18), this difference is significant at the level of $99 \%$.

Table 4-18: Significance of Friedman test for factors associated with economic factors

\begin{tabular}{|l|c|}
\hline Statistical indexes & Calculated rates \\
\hline Sample & 16 \\
\hline Chi-square & 21.37 \\
\hline Degree of freedom & 3 \\
\hline Significance level & 0.00 \\
\hline
\end{tabular}

\section{Conclusion}

Given the results of the findings, the causes of lack of reception of students of vocational schools of arts, in students' opinion, in terms of educational factors, are establishment of undesirable relationship between occupation and education system and social value and status of vocational education in terms of social and cultural factors, and also the rate of income as the most important economic factors of lack of reception and in terms of individual factors, they referred to unawareness of vocational fields. Consultants also believe that the most important factors of the causes of lack of reception of students of vocational schools of arts are lack of success of vocational courses in creating and presenting educations in proportion with the need of working market in the field of educational factors and priority of employment as the most important cultural and social factors. In terms of economic factors, consultants also believe that items such as duration of the time of unemployment of the graduates can be mentioned and they have also referred to lack of curiosity about how technical tools work. Therefore, it can be said that, given the results of the findings, although vocational education is an efficient tool for realization of the purposes written in in upstream documents such as vision document; because among purposes of vision document are the realization of a population with improved knowledge and supreme share of human capital in national production and existence of a proper system of vocational education which are among the necessary requirements of achieving such purposes. Thus, as the fourth program continues, the fifth program of development has also emphasized this by using these tools for realizing the purposes of the program which itself is a part of the programs of vision realization. Unfortunately, many students and their parents aren't aware of the main function of the vocational educations and they consider this type of education to be more for fun and entertainment than a kind of value. Official education in Iran has been seeking to educate people proper for official jobs since the beginning. Since these people are considered to be important in the society, families encourage their children to get governmental and administrative jobs and force them to study majors with physical and handy works as a result. Thus, gradually, based on an inaccurate belief, vocational educations have been put in the less prioritized social importance. Based on this, it is necessary for the ones responsible for education, school consultants and even media attempt to make parents and students more aware.

\section{References}

Azad, Ebrahim (2006); success factors in vocational education systems, growth of vocational branch education, $2^{\text {nd }}$ period, $31^{\text {st }}$ issue, 1 $-37$

Hossein Zadeh Yoosefi, Gholam Hossein (2012); vocational educations with a soft specialist approach, growth of vocational education Khalaghi, Ali Asghar (2006); "role and importance of vocational educations in economic developments", growth of vocational branch 
education, $1^{\text {st }}$ period $3^{\text {rd }}$ issue, spring of 2006, p $13-16$

Riahi, Mohammad (2005); review of family and social factors associated with selection of training field in centers of vocational education of Mazandaran province, social, economic, scientific and cultural monthly journal of work and society

Sarizadi, Seyedeh Jamileh and Sarizadi, Asieh Sadat (2012); vocational education and training skilled technicians in Iran, growth of vocational education, $8^{\text {th }}$ period, $2^{\text {nd }}$ issue

Salimi, Mostafa and Mortazavi, Saeed (2005); human capital and entrepreneurship in vocational approach (case study of Khorasan), journal of knowledge and development, $17^{\text {th }}$ issue, $p 3-20$

Sarmad, Zohreh and Bazargan, Ali and Hejazi (2004); research methods in behavioral sciences, Tehran: Agah publications

Sharifi, Asghar and Islamieh, Fatemeh (2012); causes of tendency and lack of tendency towards vocational educations, growth of vocational education, $8^{\text {th }}$ period, $1^{\text {st }}$ issue, $\mathrm{p} 21$-28

Lankarani, Mahnaz (2001), review of executive problems of vocational education, Amouzeh quarterly, $14^{\text {th }}$ issue

Yar Mohammadian, Mohammad Hossein, Jamal Zadeh, Seyed Reza (1998), review of effective factors on tendency towards the vocational branch of new system of high school education from this field's students' perspective in the city Isfahan, journal of research in psychology, 2nd issue, p $135-144$

A insworth، J.W.\& Roscing، V.J (2005). Stratfiction، school-work Linkages and vocational Education Social Forces، 84 (1)، pp. 259 -289.

Carnoy، M.(1995). "Efficiency and Equality In locational education and training", International libor Review, 133

Cornford، L.R.(1999). "Rediscovering the importance of learning And curriculum in locational education and training in Australia". Journal of locational education and training، vol. 51، no.1

Dronkers، J.(1993) the precarious Blance Between general And locational education in the Netherland Earopan Jornal of education، 28 (2) pp 197-207. Education in Secondary schools: Impact of federal and state Policies، RAND (MR-1655).

Ghost‘S. (2002). VET in schools: the needs of industry. NICORN, 28 (3), PP 61-64

Halasz، I.M (1989). Evaluation of Strategies for locational Program Redesign; ERIC Digest No. 84

Loo، R (2002). "The Delphi Method: a powerful tool for Strategic management" policing، an international Journal of polics Strategies And management، Vol. 25، No. 4، 762-769

Saunders. M \& lewis، P.(2003): Research Methods For Business students، prentice hall، Harlow، England، social change، Vol. 40، pp. 131-150.

Schaapa، H. \& Bruigna، E \& Schaafa، V \& Kirschnerb، P.A (2009); Students' personal professional theories in competence- based vocational education: the construction of personal knowledge through internalization and socialization، Journal of vocational education and training، Vol. 61، No. 481-494 